\title{
Potato yield and quality as a function of the plant density
}

\author{
EERO VARIS \\ The Hankija Plant Breeding Institute, 04300 Hyrylä, Finland
}

\begin{abstract}
The effects of potato plant density on yield quantity and quality were investigated at the Hankkija Plant Breeding Institute from 1971-73, using seed rates of 1600,3200 and $4800 \mathrm{~kg} / \mathrm{ha}$, and seed sizes of 40,80 and $120 \mathrm{~g}$. The varieties used were Ijsselster and Record.

The number of stems per $\mathrm{m}^{2}$ rose with increasing seed rate and with increasing seed size. Stem number increased with seed rate faster for small seed than for large. The response in stem number was greater for Ijsselster than for Record. The number of stems per seed tuber fell as the plant density rose.

The number of tubers per $\mathrm{m}^{2}$ altered in the same direction as the number of stems, but less responsively. The reason for this was that the number of tubers per stem decreased with increasing plant density.

The tuber yield showed a continual increase with increasing plant density. At the lowest stem densities (less than $20-25$ stems $/ \mathrm{m}^{2}$ ) small seed gave better results than other sizes, but at the higher plant densities, the importance of seed size faded away and the yield was dependant on the plant density alone. Net yield (gross yield $-2 \mathrm{x}$ seed rate), however, was higher the smaller the seed used, whatever the stem density.

Tuber size decreased when plant density increased, the proportion of large tubers diminishing most, especially when small seed was used. The proportion of small tubers altered more for Ijsselster than for Record.

Seed size and seed rate did not on average significantly affect the proportion of Class I potatoes, though small seed gave results slightly better than other sizes.

The starch content of the yield rose when the seed rate was increased (16.0$16.3-16.5 \%)$ and fell with increasing seed size $(16.5-16.2-16.1 \%)$. The maximum variation was $15.8-16.7 \%$.

The specific gravity distribution improved with increasing plant density.

Raw discolouration of the tubers did not alter significantly as the plant density rose.

Blackening of the tubers decreased with increasing plant density when small and medium sized seed were used.

Mealiness of the tubers was somewhat higher for small seed than for other seed sizes.
\end{abstract}

Potato plant density is nowadays taken to mean the number of main stems per unit area (Bleasdale 1965). In the past, plant density has been regulated by choice of seed size and spacing ignoring factors relating to the production of stems on the tubers. However, the results thus attained are rather rough, since the capacity of a given seed size to produce stems varies considerably with variety, seed quality and treatment (DENT and HAL- 
KON 1969). Likewise weight of the tubers and number of stems produced by them are not linearly related (VARIS $1973 \mathrm{a}$ ).

For this reason the definition given above has been adopted, and plant density has been assessed from the capacity of seed tubers to produce stems. However, this requires a better understanding of the factors affecting the formation of stems from seed potatoes, and of the methods used for determining stem numbers, than we have at present (Hagman 1973).

It has been shown that under intensive cultivation a moderate degree of change in plant density has hardly any effect on gross yield, and even less on net yield, since the potato has a fairly good capacity for using spare room either by increasing the number of tubers per stem, but mainly by increasing tuber size (DAmbroth and PÄTzold 1969). There is less information as to how variations in plant density are reflected in quality of the crop, excepting variation in tuber size (WARREN 1958, Bleasdale and THOMPSON 1969).

An attempt is made in this study to investigate the effects of seed size and rates upon plant density, and the effects of plant density upon yield and quality.

\section{Materials and methods}

The material comprises four experiments from 1971-73. Three of the experiments were made at the Anttila Experimental Farm, and one was made at the field site in Viskaali, Muhos in 1972. The treatments were as follows:

\begin{tabular}{lrl}
\hline Seed rates & Seed sizes & Varieties \\
\hline $1600 \mathrm{~kg} / \mathrm{ha}$ & $40 \mathrm{~g}$ & Rekord \\
3200 & 80, & Ijsselster \\
4800 & 120 & \\
\hline
\end{tabular}

The treatments $1600-40,3200-80$ and $4800-120$ contained the same number of tubers per unit area.

There were two replicates, the plot size was $10.05 \mathrm{~m}^{2}$ and the experimental layout a factorial design. The soil type at Anttila was loam underlaid by heavy clay, at Muhos finer finesand. The fertilizer rate was 1200 $\mathrm{kg}$ of a chloride-free complete N-P-K fertilizer $(7-11-12)$ per hectare, drilled across the plots. The ridges were spaced at $67 \mathrm{~cm}$ and within the ridges the following planting distances were used:

\begin{tabular}{|c|c|c|c|c|}
\hline $1600-40$ & $37 \mathrm{~cm}$ & ........... & 40.000 & tubers/ha \\
\hline $1600-80$ & 75 . & ............ & 20.000 & , \\
\hline $1600-120$ & 112 & $\ldots \ldots$ & 13.300 & , \\
\hline $3200-40$ & $19 \mathrm{~cm}$ & ...... & 80.000 & tubers/ha \\
\hline $3200-80$ & 37 & .... & 40.000 & , \\
\hline $3200-120$ & 56 & & 26.700 & , \\
\hline $4800-40$ & $12 \mathrm{~cm}$ & & 120.000 & tubers $/ \mathrm{h}$ \\
\hline $4800-80$ & 25 & & 60.000 & 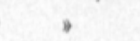 \\
\hline $4800-120$ & 37 & & 40.000 & , \\
\hline
\end{tabular}


The average date of planting the experiments was the 26th of May, that of lifting the 14th of September. Normal cultivation techniques were used. A "Nosto-Juko" potato harvester was used to lift the crop, and the remaining small potatoes were gathered by hand.

The following determinations were made upon the stands and harvested tubers:

1. Number of main stems $/ \mathrm{m}^{2}$. The stems were counted at the end of August.

2. Number of tubers $/ \mathrm{m}^{2}$. The tubers were counted when the yield was weighed.

3. Tuber yield tons/ha.

4. Tuber size distribution (\%). The yield was sorted using 40 and $55 \mathrm{~mm}$ sieves.

5. Class I yield $(\%)$. The proportion of the yield meeting Class I standards as specified in the Finnish statute for table potatoes was assessed after sampling for starch content determinations.

6. Specific gravity distribution (\%). The plot yields were sorted using salt solutions $\left(+18^{\circ} \mathrm{C}\right)$ at five SG levels: less than $1.065,1.065-1.075,1.075-1.085,1.085-1.095$, and over 1.095 .

7. Starch content. For starch determinations, $5 \mathrm{~kg}$ samples were taken from the plot yield. The weight in water was converted to starch- $\%$ according to the tables of Hals \& Bucholz.

8. Raw discolouration. The determination was made on a $100 \mathrm{~g}$ sample of raw chips 12 hours after cutting. Scale $0-100(100=$ no discolouration, $0=$ completely discoloured $)$.

9. Blackening. 5 peeled tubers were cooked. Blackening was determined after 12 bours. Scale as above.

10. Sloughing. The mealiness of the potatoes was assessed from the amount of disintegration in 5 boiled, previously peeled tubers. Scale $0-100(0=$ intact, $100=$ completely sloughed).

The analyses of variance used for the statistical treatment of the results were calculated in the ADP department of the Hankkija Cooperaticve Centre. Significance levels for the results are shown in the usual manner.

\section{Results and discussion}

The results of the analyses of variance are shown in Table 1 .

\section{Number of stems}

The mean number of stems varied from trial to trial $(23-21-23-32$ stems $/ \mathrm{m}^{2}$ ). The value for 1973 trial clearly deviated from values for the other trials. There were also differences between the varietal means (Record 21, Ijsselster 32 stems $\left(\mathrm{m}^{2}\right)$, varying yearly (AD). An increase in seed size and seed rate increased the number of stems in every trial (B, C, AB and $A C$ ). The interaction between seed size and rate was significant (BC) as were the interactions seed size $\times$ variety $(\mathrm{BD})$, seed rate $\times$ variety $(\mathrm{CD})$ and seed size $\times$ seed rate $\times$ variety $(B C D$, Fig. 1$)$. There was yearly variation in these interactions ( $A B D, A C D)$ except for the interaction $B C$, which was similar in all the experiments.

The number of stems increased with seed rate more rapidly for small seed than for large. The effect was readily discernible with Ijsselster. The 
Table 1. Analysis of variance of the effects of plant density on yield and quality of potatoes.

\begin{tabular}{|c|c|c|c|c|c|c|c|c|c|c|}
\hline Factor & 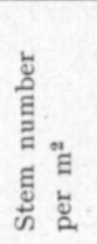 & 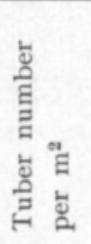 & 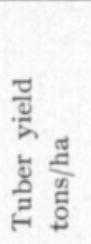 & 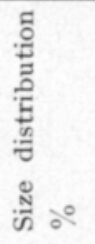 & 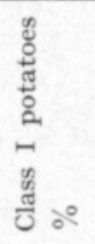 & 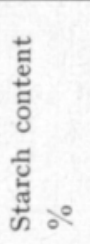 & 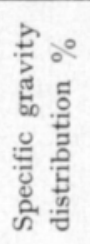 & 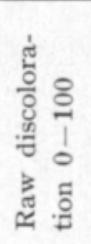 & 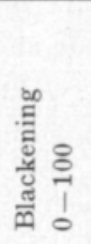 & 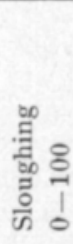 \\
\hline A. Trial ........ & $* * *$ & $* * *$ & $* * *$ & $* * *$ & $* * *$ & $* * *$ & $* * *$ & $* * *$ & $* * *$ & $* * *$ \\
\hline B. Seed size . & $* * *$ & $* * *$ & $* * *$ & $* * *$ & ns & $* * *$ & $* * *$ & ns & ns & ns \\
\hline C. Seed rate. & $* * *$ & $* * *$ & $* * *$ & $* * *$ & ns & $* * *$ & $* * *$ & ns & $(*)$ & ns \\
\hline D. Variety .... & $* * *$ & $* * *$ & $* *$ & $* * *$ & $* * *$ & $* * *$ & $* * *$ & $* * *$ & $*$ & ns \\
\hline AB $\ldots \ldots \ldots \ldots \ldots$ & ns & ns & ns & ns & ns & ns & $* *$ & ns & ns & $* * *$ \\
\hline $\mathrm{AC}, \ldots \ldots \ldots \ldots \ldots$ & ns & ns & ns & $* *$ & * & ns & $* *$ & ns & ns & $* * *$ \\
\hline AD $\ldots \ldots \ldots \ldots \ldots$ & $* * *$ & $* * *$ & $* * *$ & $* * *$ & $* * *$ & ns & ns & $(*)$ & ns & $(*)$ \\
\hline BC $\ldots \ldots \ldots \ldots \ldots$ & $(*)$ & ns & ns & ns & $(*)$ & $* * *$ & $* * *$ & $(*)$ & ns & $* * *$ \\
\hline BD $\ldots \ldots \ldots \ldots \ldots$ & $* * *$ & * & ns & ns & $* * *$ & ns & $*$ & ns & ns & ns \\
\hline CD $\ldots \ldots \ldots \ldots \ldots$ & $* * *$ & $* * *$ & ns & $*$ & ns & $*$ & ns & ns & ns & ns \\
\hline ABC $\ldots \ldots \ldots \ldots$ & ns & ns & ns & ns & ns & ns & $* * *$ & $(*)$ & $(*)$ & $(*)$ \\
\hline ABD .............. & $* *$ & ns & ns & ns & ns & ns & ns & $(*)$ & ns & ns \\
\hline ACD $\ldots \ldots \ldots \ldots$ & $* *$ & ns & ns & ns & ns & ns & ns & ns & ns & ns \\
\hline BED .............. & $* *$ & ns & ns & ns & ns & ns & ns & ns & ns & ns \\
\hline
\end{tabular}

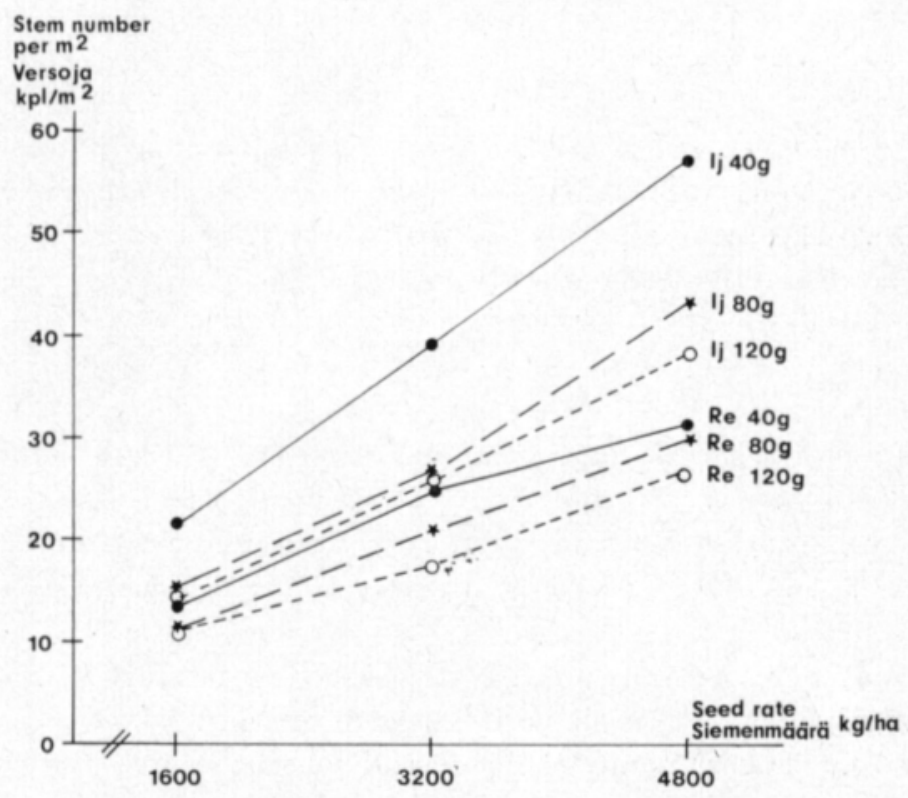

Figure 1. The effects of seed size and rate on the stem number per $\mathrm{m}^{2}$.

stem number was less responsive to seed rate in the case of Record and the rate of increase of stem number was less dependent upon seed size. In nearly all cases the number of stems increased almost linearly. 
It is apparent from Fig. 1 that a good plant density is more readily achieved by reducing seed size and spacing than by increasing seed size. The reason for this is that small or rather small tubers have, weight for weight, more shoots than large ones (cf. VARIS 1973 a). Naturally, if seed tuber spacing is held constant, a higher plant density is achieved with large than with small seed tubers.

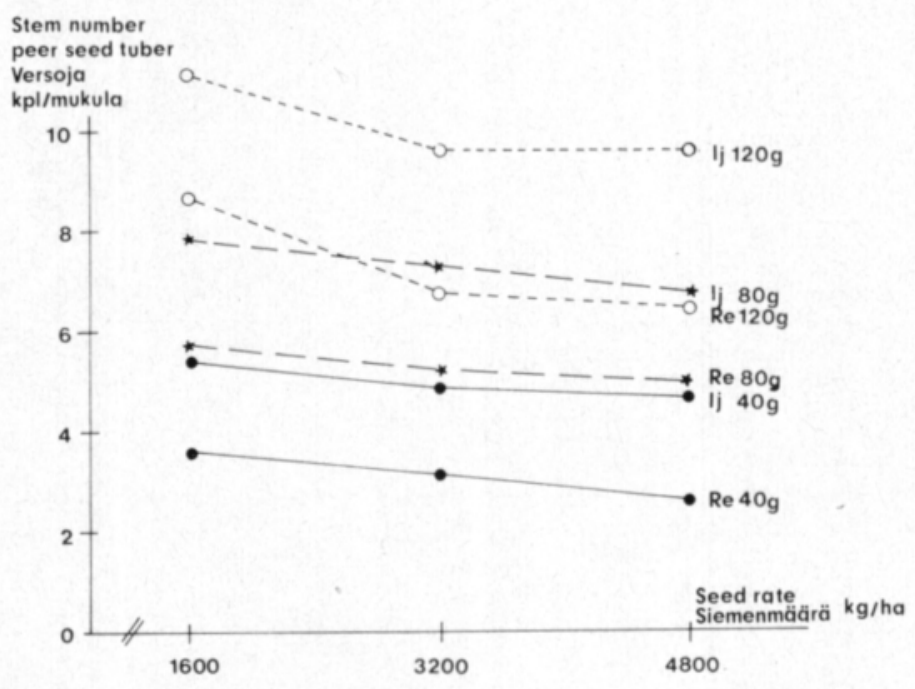

Figure 2. The effects of seed size and rate on the stem number per seed tuber.

An increase in seed rate, however, caused a reduction in the number of stems per seed tuber, apparently because of competition between adjacent hills (Fig. 2). The stem number fell with increasing seed rate, particularly when large seed was used (cf. Morris 1967).

\section{Number of tubers}

The number of tubers varied in the four trials $\left(52-51-46-68\right.$ tubers $\left./ \mathrm{m}^{2}\right)$. An increase in seed rate and in seed size increased the tuber density (B and C). Numbers of tubers were different for the two varieties (Ijsselster 68, Rekord 40 tubers $\left(\mathrm{m}^{2}\right)$. The interactions for number of tubers were fewer than for number of stems. Thus the interaction seed size $\times$ seed rate (BC) was not significant, nor were any of the second degree interactions.

Numbers of tubers for both varieties were greatest when small seed was used (Fig. 3). Tuber numbers increased when the seed rate was raised, though not in proportion to stem numbers (cf. Table 2).

When small or medium-sized seed was used, the number of tubers per stem was on average a bit larger than when large seed was used (2.2$2.2-2.1)$. The number of tubers per stem fell when the seed rate was increased (2.5-2.2-1.8) (cf. Houghland and Akeley 1959, Dambroth and PÄTZOLD 1969, VARIS 1973 a). 


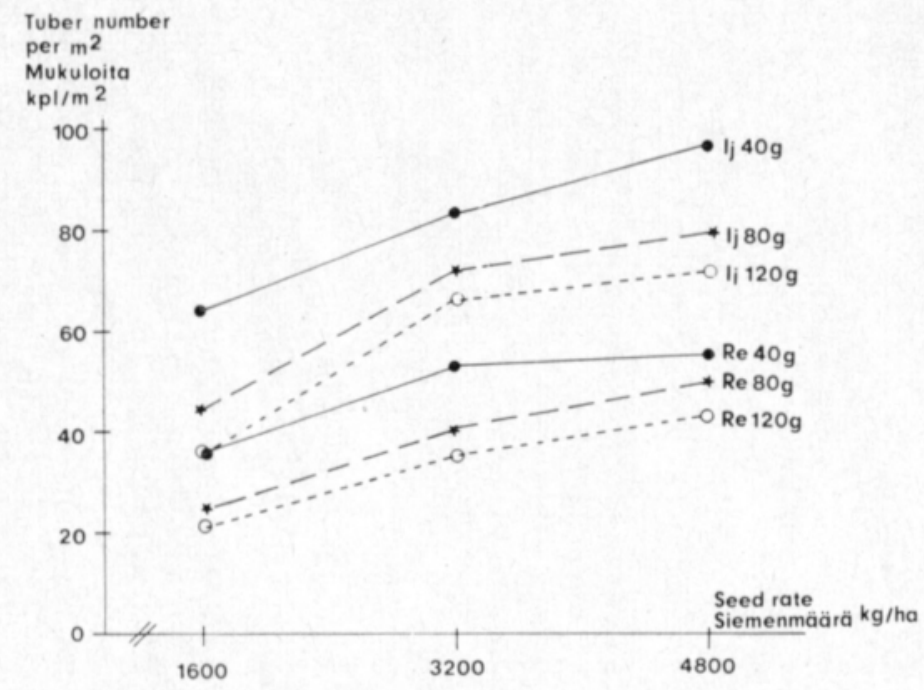

Figure 3. The effects of seed size and rate on the tuber number per $\mathrm{m}^{2}$.

Table 2. The effect of the seed rate and size on the tuber number per stem.

\begin{tabular}{|c|c|c|c|}
\hline Treatment & Ijsselster & Record & Mean \\
\hline 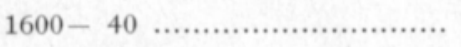 & 3.0 & 2.5 & 2.8 \\
\hline 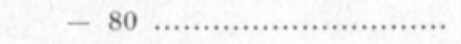 & 2.9 & 2.2 & 2.6 \\
\hline 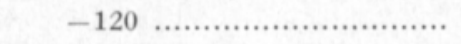 & 2.4 & 1.9 & 2.2 \\
\hline Mean & 2.8 & 2.2 & 2.5 \\
\hline 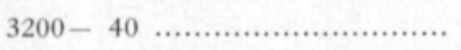 & 2.1 & 2.1 & 2.1 \\
\hline 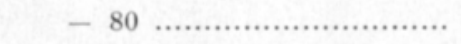 & 2.6 & 1.9 & 2.3 \\
\hline 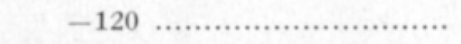 & 2.6 & 2.0 & 2.3 \\
\hline 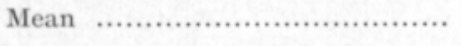 & 2.4 & 2.0 & 2.2 \\
\hline $4800-40$ & 1.7 & 1.8 & 1.8 \\
\hline 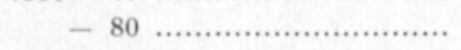 & 1.8 & 1.7 & 1.8 \\
\hline 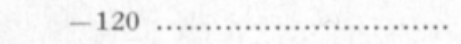 & 1.9 & 1.6 & 1.8 \\
\hline 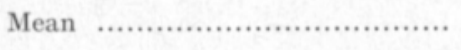 & 1.8 & 1.7 & 1.8 \\
\hline $40 \ldots \ldots \ldots \ldots \ldots \ldots \ldots \ldots \ldots$ & 2.2 & & \\
\hline 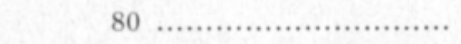 & 2.2 & & \\
\hline 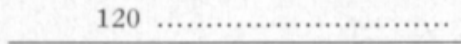 & 2.1 & & \\
\hline
\end{tabular}

\section{Yield of tubers}

The yield of tubers varied in a normal manner from trial to trial (A). The mean yields of the varieties were different (Ijsselster 26.96 tons/ha, Record 25.35 tons/ha). The seed rate influenced yield $(20.36-27.32-30.80$ tons/ha) as did seed size $(28.88-25.60-24.00$ tons/ha). Only the interaction trial $\times$ variety $(\mathrm{AD})$ was significant. There was no significant interaction of seed rate and seed size upon yield. 


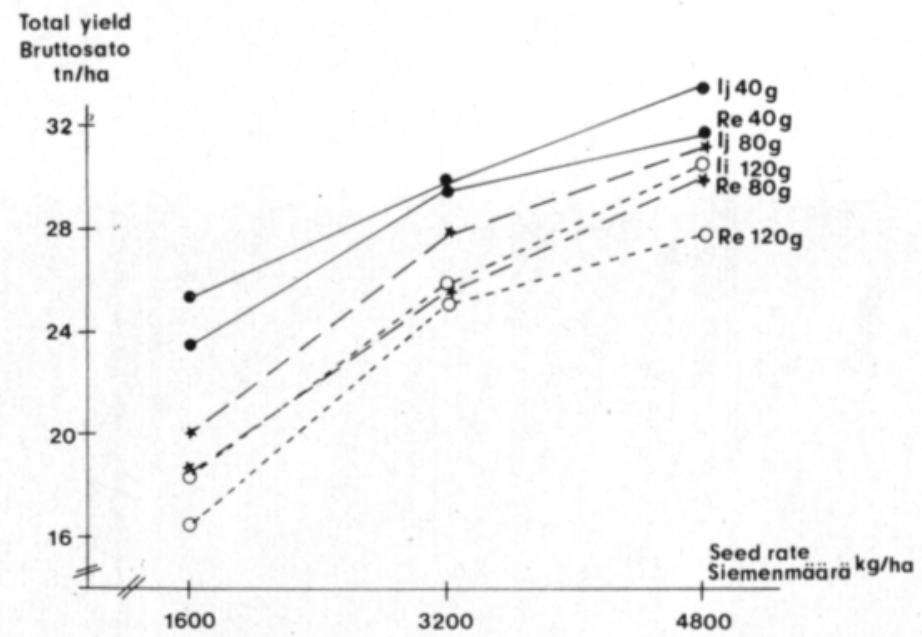

Figure 4. The effects of seed size and rate on the tuber yield.

Small seed produced higher yields of both varieties (Fig. 4). The yield increased as the seed rate was increased, though not linearly. The same trend was shown by Pohjonen and PaAtela (1974).

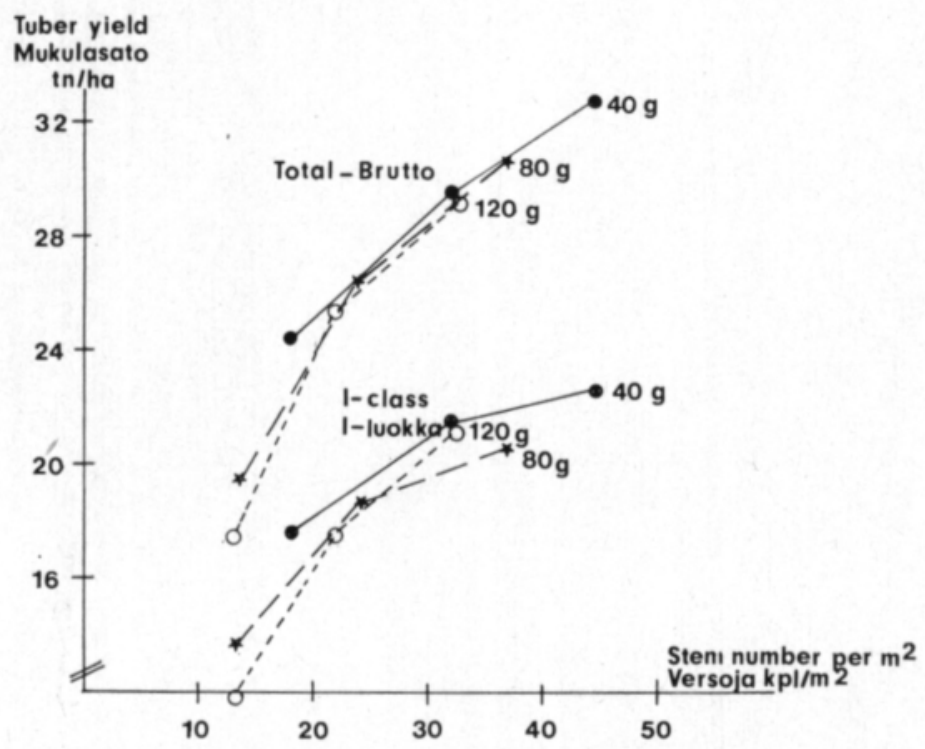

Figure 5. The effect of stem density on the tuber yield and quality.

The yield data have been plotted as a function of stem densities in Fig. 5. When the stem density increased from 20 to 40 stems $/ \mathrm{m}^{2}$, the yield rose almost linearly by about 7 tons, or $350 \mathrm{~g}$ for each additional stem. At low stem densities, small seed gave better yields than larger sizes. However, at higher stem densities the effect of seed size lost much of its importance, and the yield seemed mainly dependent upon the number of 
stems per unit area (cf. Holmes 1966). The varieties differed in that Record produced a higher yield per stem than Ijsselster, although Record gave on average a poorer total yield due to its smaller number of stems.

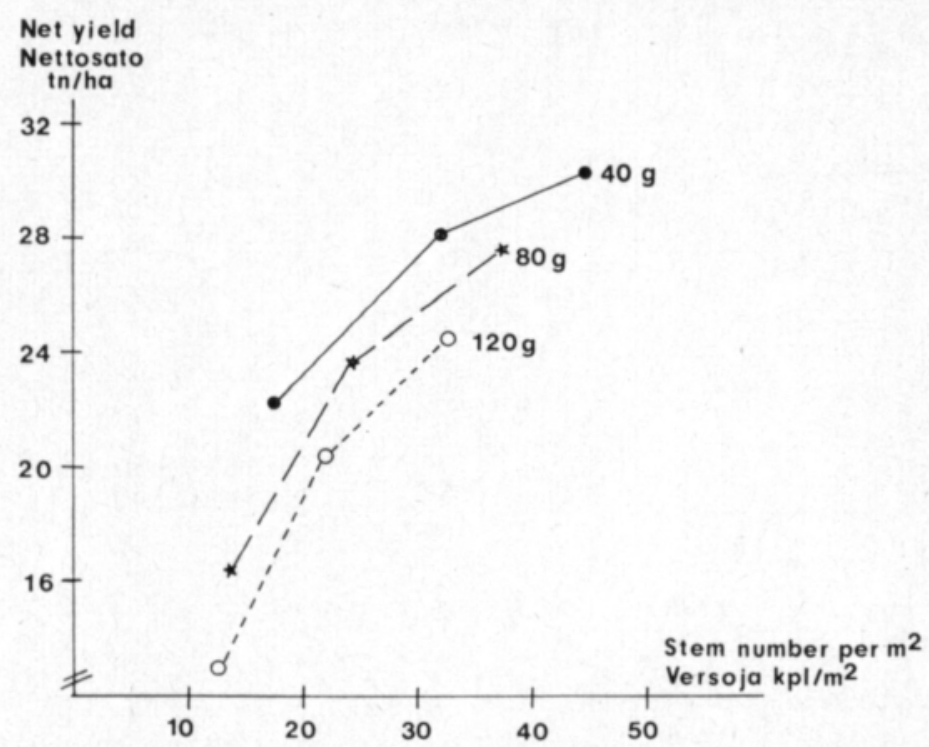

Figure 6. The effect of stem density on the net yield (net yield $=$ total yield $-2 \times$ seed rate).

As well as gross yields, net yields are shown in Fig. 6. Net yields are estimated using the formula gross yield $-2 \times$ seed rate $=$ net yield. The smallest seed gave the best result at all stem densities. The reason for this is that small seed has the most sprouts and tubers for a given weight (cf. VARIS 1973 a).

\section{Size distribution}

All the treatments had a significant effect upon size distribution. There was yearly variation in the effects of seed rate and seed size (AC and AD). Also the interaction seed rate $\times$ variety $(C D)$ was significant.

The proportion of large tubers in the yield fell both with increasing seed rate and with decreasing seed size. (Fig. 7). This is the predictable consequence of changes in plant density and yield (cf. DAмBrot and Pätzold 1969). According to THOMPSON and TAYLOR (1974), as plant density increases, tuber size soon levels off at a density of $70 \mathrm{stems} / \mathrm{m}^{2}$. The results of this study show the same trend.

An increase in the seed rate increased the number of small tubers for Ijsselster more than for Record (Ijsselster 11-16-18\%, Record 4-5-5\%).

The two factors determining potato yielding capacity are the number of tubers and their size. To produce tubers of a given size, one must adjust the plant density on the basis of the expected yield (cf. VARIs 1971). In the regulation of plant density, not only seed size but also the variety 


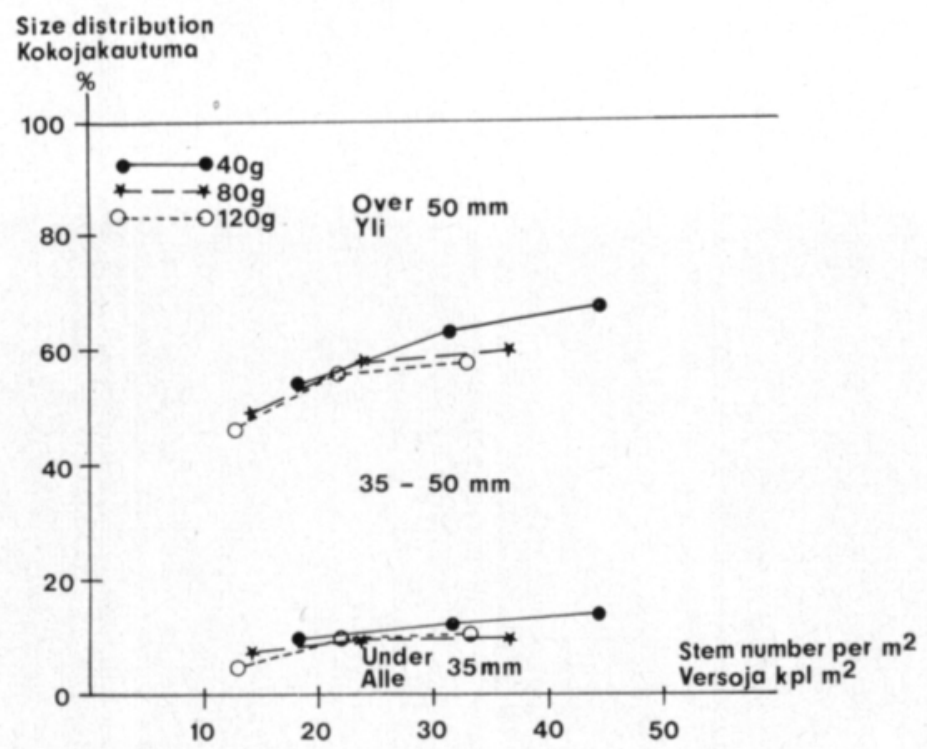

Figure 7. The effect of stem density on the size distribution.

must be considered, as varieties differ in their capacity to form stems and tubers (VARIS $1973 \mathrm{~b}$ ). The simplest way of determining the planting rate would be to use the number of sprouts capable of developing shoots per tuber planted (cf. germination percentage of cereals), always provided that a reliable method of determination could be devised (Hagman 1973).

\section{Proportion of Class I yield}

The proportion of Class I yield varied greatly from trial to trial (54$83 \%$ ). There was also a difference between varieties (Ijsselster $78 \%$, Record $62 \%$ ). Seed rate and seed size, however, caused on average no significant differences. In fact, the effects of seed rates were conflicting in different trials (AD). The interaction seed rate $\times$ seed size was slightly significant (Fig. 5). Small seed produced the largest yield of class I potatoes, but the increase in class I yield with increasing plant density levelled off faster than did the gross yield, and usually reached a plateau at a stem density of $40-50 \mathrm{stems} / \mathrm{m}^{2}$, depending upon seed size.

\section{Starch content}

The mean starch content varied yearly $(15.1-17.1 \%)$ and with variety (Ijsselster $16.7 \%$, Record $15.8 \%$ ). The seed rate and seed size also influenced starch content (Fig. 8).

The starch content rose with increasing seed rate $(16.0-16.3-16.5)$ and fell with increasing seed size $(16.5-16.2-16.1 \%)$. Judging from these trends, it would seem that the high plant density attainable by the use of small seed is favourable for starch production (cf. Bleasdale and Thompson 1969). 


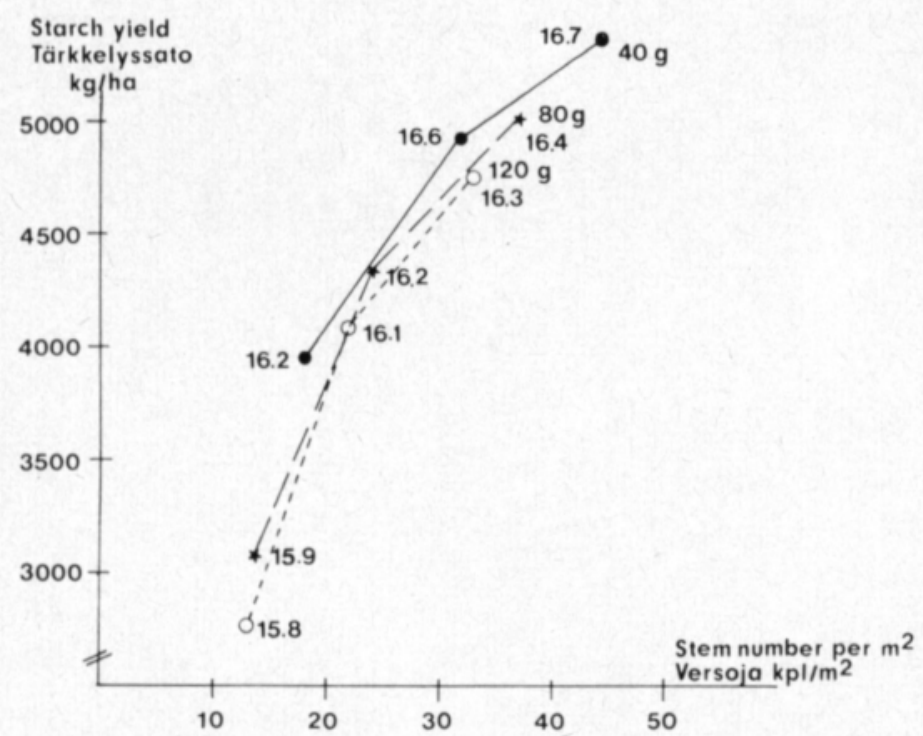

Figure 8. The effect of stem density on the starch yield and starch content.

\section{Specific gravity distribution}

The specific gravity distribution varied yearly and with variety. An increase in seed size caused a wider distribution, and a higher seed rate narrowed the distribution (Fig. 9). In general, the higher the mean starch content of

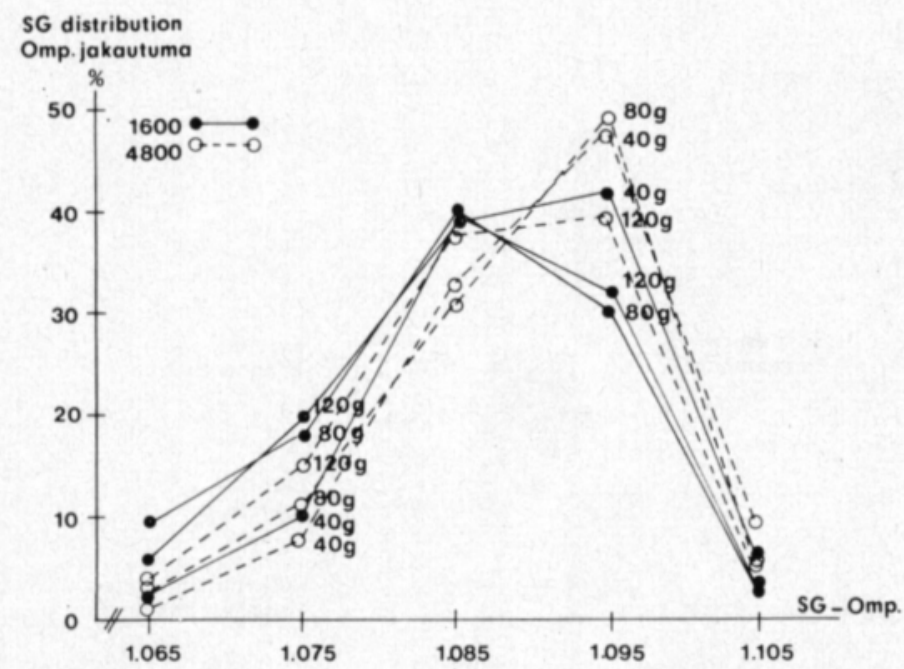

Figure 9. The effects of seed size and rate on the SG distribution.

the yield, the larger the proportion of tubers approaching the genetic starch content maximum for a variety, and the larger the proportion of tubers falling into high specific gravity classes. 


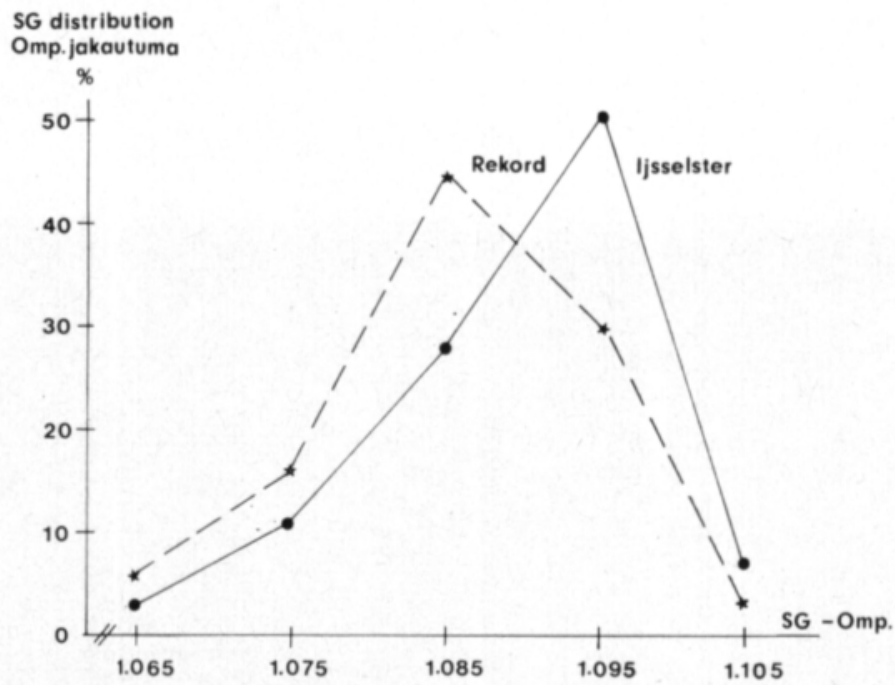

Figure 10. The SG distributions of the cultivars Ijsselster and Record.

The specific gravity distribution of Record was less favourable as regards yield quality, than that of Ijsselster (Fig. 10).

\section{Raw discolouration}

There were yearly and varietal differences in raw discolouration. Neither seed size nor seed rate caused on average any significant changes, though the results in different trials were conflicting $(\mathrm{AB}, \mathrm{AC})$. The interaction $\mathrm{BC}$ was slightly significant (Fig. 11). Large seed behaved differently from other sized seed, which observation is difficult to account for.

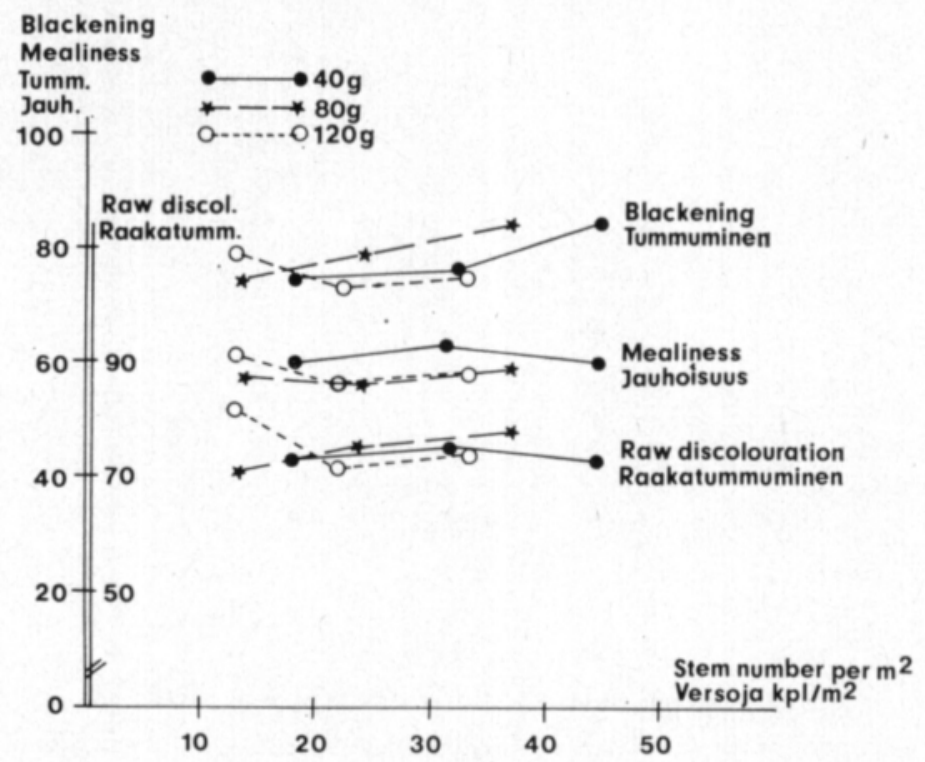

Figure 11. The effect of stem density on the cooking quality. 
Blackening also varied yearly and with variety (A, D). Also an increase in seed rate reduced blackening slightly (C), when small and medium sized seed was used (Fig. 11). Bleasdale and Thompson (1969) arrived at the same result.

\section{Sloughing}

The mealiness of potatoes was estimated from the extent of disintegration on cooking. Only yearly variation (A) was found. A slight interaction $\mathrm{BC}$ indicated that small seed produced more mealy potatoes than larger seed sizes, especially when intermediate seed rates were used (Fig. 11). In studies of BLEASDALE and Thompson (1969), an increase in plant density aggravated the tendency of potatoes to slough.

\section{Conclusions}

The results on potato plant density presented here, as well as those elswhere, show that the optimum plant density is achieved most easily by using fairly small seed. The actual optimum plant density to be used depends upon the cultivation conditions and upon variety. However, under Finnish conditions it would seem relatively high, $30-40$ main stems per $\mathrm{m}^{2}$, compared with the recommendation of $20-25$ main stems per $\mathrm{m}^{2}$ used in Holland, for instance (van der ZAAG 1973). This, from our point of view unfavourable situation may be due to the fact that the ability of our seed to produce tubers per stem is poorer than that of seed in Central Europe. On the other hand, the shortness of our growing season involves a need of a large assimilating leaf area relative to the size of the developing yield, so that the quality of the yield can attain a high standard.

From what has been stated, it follows that under Finnish conditions, the seed requirement per unit planting area is larger than in Central Europe. To mitigate against this disadvantage, we should continue to investigate all the factors associated with the characters of seed potatoes, and of growing conditions, so that large seed rates and high costs could be reduced without any sacrifice in yield, and particularly in quality.

\section{Acknowledgements}

I wish to express my deep gratitude to The Academy of Finland for the two-year appointment that gave me the opportunity for completing this and a series of previous papers on potatoes. Likewise, I would like to thank my usual employer, The Wholesale Co-operative Society Hankkija, and expecially my superior, dr. Erkki Kivi for his support of investigations falling outside the normal routine of the Institute. 


\section{REFERENCES}

Bleasdale, J. K. A. 1965. Relationship between set characters and yield in maincrop potatoes. J. Agric. Sci. Cambr. 64: 361-366.

- - - \& Thompson, R. 1969. Some effects of plant spacing on potato quality. Eur. Potato J. 12: 173-187.

Dамввотн, M. \& PÄtzold, CH. 1969. Mineraldüngung, Erntetermin, Sorte, Standraum und Pflanzgutgrösse in ihrem Einfluss auf die Ertragsstruktur der Kartoffel. Völkenrode 19: $29-38$.

Dent, J. B. \& Halkon, W. S. 1969. Influence of time of sprouting and weight of stored seed tubers on the production of sprouts and shoots. Eur. Potato J. 12: 49-58.

Hagman, C-G. 1973. Quality of seed potatoes - properties and relationships. Dep. Pl. Husb. Agric. Coll. Uppsala. 83 p.

Holmes, J. C. 1966. Seed size and spacing for seed and ware potato crops. Scott. Agric. 45: $176-180$.

Hougland, G. V. C. \& Akeley, R. V. 1959. Effects of seed spacing and fertilizer rate on field performances of potato varieties and on financial return. Amer. Potato J. 36: $227-234$.

Morris, D. A. 1967. Intersprout competition in the potato II. Competition for nutrients during pre-emergence growth after planting. Eur. Potato J. 10: 296-311.

Pohjonen, V. \& PaAtela, J. 1974. Effect of planting interval and seed tuber size on the gross and net potato yield. Acta Agric. Scand. 24: 126-130.

Thompson, R. \& TAYLOR, H. 1974. Stem density and maturation studies with the potato cultivars Maris Peer and Pentland Marble. Potato Res. 17: 51-63.

VARIS, E. 1971. Siemenperunan käyttö tehokkaaksi. Pellervo 72: $430-431$.

- - 1973 a. The effects of tuber size and chitting method on the growth and yield of Amyla and Barima potatoes. J. Scient. Agric. Soc. Finl. 45: 297-318.

- -1973 b. Perunalajikkeiden mukulanmuodostuskyky. Koetoim. ja Käyt. $30: 37$.

WARREN, G. C. 1958. The influence of type of set and planting distance on grades and yields of potatoes for seed. Amer. Potato J. 35: 733-738.

Van der ZAAG, D. E. 1973. Requirements of the user of seed potatoes. EARP Proceedings, 5th Trienn. Conf., 38-46. 


\title{
Perunasadon määrä ja laatu kasvutiheyden funktiona
}

\author{
Eero Varis \\ Hankkijan kasvinjalostuslaitos, Anttilan koetila, 04300 Hyrylä
}

Perunan kasvutiheyden vaikutusta sadon määrään ja laatuun selvitettiin vuosina 197173 Hankkijan kasvinjalostuslaitoksella käyttäen siemenmäärıä 1600, 3200 ja $4800 \mathrm{~kg} / \mathrm{ha}$ ja siemenkokoja 40, 80 ja $120 \mathrm{~g}$. Lajikkeina olivat Ijsselster ja Rekord.

Versoluku/m² kasvoi siemenmäärän suuretessa ja siemenkoon kasvaessa. Siemenmäärää lisättäessä versoluku kasvoi pienellä siemenellä nopeammin kuin isolla. Ijsselsterin versoluku muuttui enemmän kuin Rekordin. Versoluku/siemenmukula aleni kasvutiheyden suurentuessa.

Mukulaluku/m² muuttui samansuuntaisesti kuin versolukukin, mutta ei yhtä nopeasti. Tämä johtui siitä, että mukulaluku/verso aleni kasvutiheyden suurentuessa.

Mukulasato suureni jatkuvasti kasvutiheyden lisääntyessä. Alhaisissa versotiheyksissä (alle $20-25 \mathrm{kpl} / \mathrm{m}^{2}$ ) p eni siemen oli muita edullisempaa, mutta suuremmissa kasvutiheyksissä siemenen koon merkitys loppui ja sato oli riippuvainen vain kasvutiheydestä. Nettosato (bruttosato $-2 \times$ siemenmäärä) oli sen sijaan kaikissa versotiheyksissä sitä suurempi mitä pienempää siementä oli käytetty.

Mukuloiden koko pieneni kasvutiheyden suurentuessa siten, että isojen mukuloiden osuus väheni eniten erityisesti pientä siementä käytettäessä. Ijsselsterin pienten mukuloiden määrä muuttui enemmän kuin Rekordin.

Siemenmäärä ja siemenkoko eivät keskimäärin vaikuttaneet merkitsevästi I-luokan perunoiden osuuteen, joskin pieni siemen oli lievästi muita edullisempaa.

Sadon tärkkelyspitoisuus nousi siemenmäärää lisättäessä $(16.0-16.3-16.5 \%)$ ja laski siemenen kokoa suurennettaessa $(16.5-16.2-16.1 \%)$. Maksimivaihtelu oli $15.8-16.7 \%$.

Ominaispainojakautuma muuttui edullisemmaksi kasvutiheyden lisääntyessä.

Mukuloiden raakatummuminen ei muuttunut merkitsevästi kasvutiheyden kasvaessa.

Mukuloiden tummuminen väheni kasvutiheyden lisääntyessä pientä ja keskikokoista siementä käytettäessä.

Mukuloiden jauhoisuus oli pientä siementä käytettäessä osittain korkeampi kuin muilla. 